Profile

\title{
Joy and discovery are inseparable from academic commitment
}

\author{
Constantine A Stratakis ${ }^{1,2,3}$ \\ ${ }^{1}$ Eunice Kennedy Shriver National Institute of Child Health and Human Development (NICHD), NIH, Bethesda, \\ Maryland 20892, USA \\ ${ }^{2}$ Section on Endocrinology and Genetics (SEGEN), Program on Developmental Endocrinology and Genetics, \\ CRC - Rm 1-3330, Building 10-CRC, 10 Center Drive, Bethesda, Maryland 20892, USA \\ ${ }^{3}$ Inter-Institute Pediatric Endocrinology Training Program, NIH, Bethesda, Maryland 20892, USA
}

Correspondence

should be addressed to

C A Stratakis

Email

stratakc@mail.nih.gov
Dervish Thoughts

Whirlwind mind:

Sic transit gloria mundi

Handsome present (absent joy)

A sudden look - a wish:

Air, fire, high!

Ad infinitum please!

A dance, a light, sunrise,

Crazy spring, an awkward move,

Warm, sweet life,

An insane tango!

Few people know that I write poetry ... until today that is. Although I have published poems and other writing before, I have kept this activity separate from my life as a researcher and a physician. When I was honored by the invitation to write this profile for Endocrine-Related Cancer, I decided that it was time to reveal my nonscientific writings to this audience. The truth of the matter is that the arts, and especially the classics, poetry, and music (opera in particular) have had a profound influence on my life, along with the outdoors, since I was a child. With time, I have realized that the wisdom that comes with exposure to the arts and the observations one makes in the outdoors feed my excitement with search and discovery in science, as well as provide unparalleled balance for soul and body, beyond mens sana in corpore sano, and closer near absolute nirvana. I am often lost in my thoughts, running in parks, forests, city streets, or along the beach (shown in the picture) - it is not unusual for me to plan my next experiment or clinical study, design a protocol, outline talks or whole manuscripts, while running. Often, the words of a poem or an essay that I have read interrupt other thoughts, typically triggered by something I see. I am then mystified by the beauty of nature but also by people and their works; it is this 'whirlwind' that I tried to capture in the poem that I call 'Dervish thoughts'. The asceticism and austerity of dervishes and their defiance of vanity, the ephemeral nature of our actions recur in my thoughts; hence my favorite sic transit gloria mundi and the desire for an infinite extension of the pleasing, without worries, present - dum vivimus vivamus! Nevertheless, and despite the sadness of the realization of the shortness of the moment, the beauty of the instant is so deeply felt that the dervish in my poem goes on with a tango ... as insane as this might be, given his formal training and religious adherence.

As far as I remember, I have always been a curious observer, fascinated by life, nature, and the arts and sciences. I started writing at about age 12 but already as an

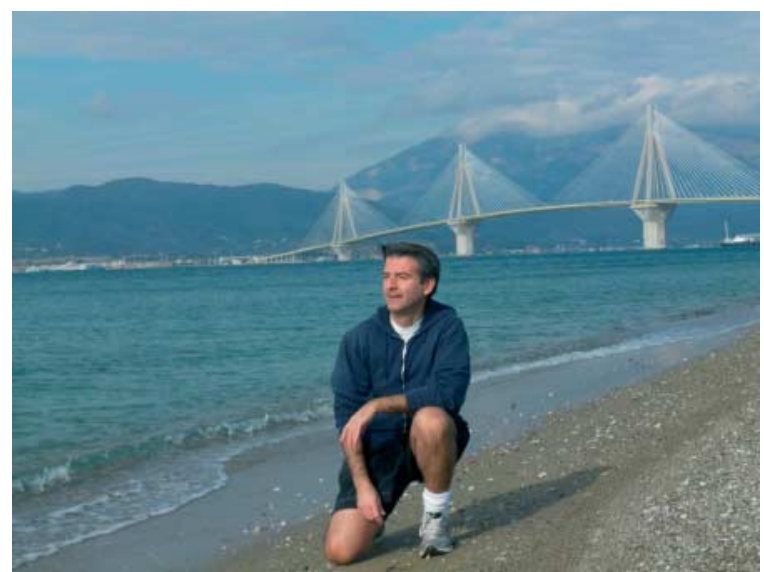

Published by Bioscientifica Ltd. 
8- or 9-year-old I was often outdoors by myself collecting artifacts from the many prehistoric, classic, and Roman sites around our summer house in Galaxidi, Greece, a picturesque little town on the Corinthian Gulf. By the age of 12 , I would take my boat to a little island that I was 'excavating' (both the boat and the natural harbor I would usually anchor in are shown in the picture below). My grandmother did not share this fascination with me: at the end of the summer season all my 'rocks' were thrown away, and I would start again the following summer.

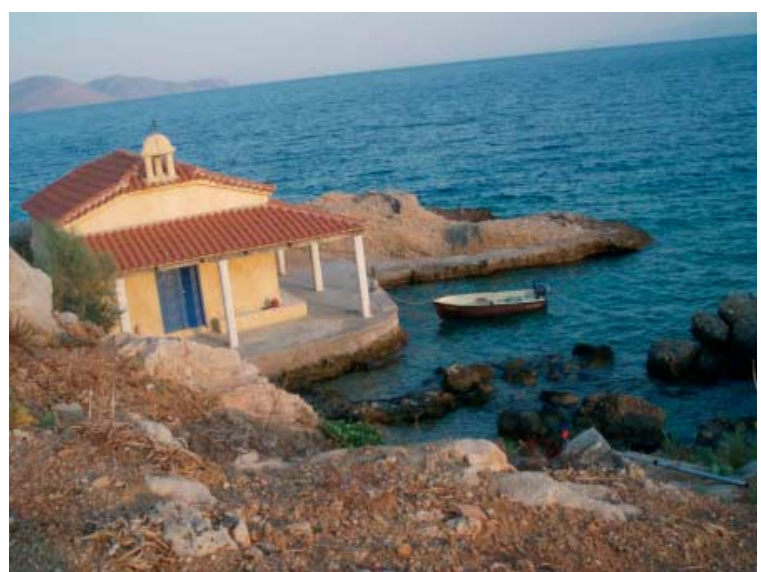

My first microscope, received at the age of 10 or so, was used to look at bugs (from cheese crust and other hideous sources that made my mother, and particularly my grandmother, always unhappy) and the occasional beer yeast. My father's brother, a biochemist, was studying spiders and, later, crab lipoproteins, and even later the class of molecules now known as lectins. I visited his laboratory in Ulm, and then in Cologne, Germany in the 1980s. I was permanently hooked! Then, as a high school student, I loved physics and, in particular, chemistry but was fascinated with biology. I was looking for ways to combine biology with physics or chemistry. My first publication, at age 17 , was in physics: a paper that received an award by the Hellenic Physics Society given annually for best papers from high school students (Stratakis 1983). At school, the Varvakios Exemplary School (a gymnasium and lyceum in Athens with a long tradition in the graduation of future scientists), I developed a hand-operated model of mitosis for a science fair. During this time, a family member was diagnosed with craniopharyngioma.

Although by then I was determined to be a biochemist or a biologist, I had my first contact not only with medicine but also with endocrinology. Reading about hormones and how they acted, I realized that endocrinology offered everything that I was looking for: chemical substances that could be measured, synthesized or used as therapies, cells that were regulating distant organs by complex regulatory loops that reminded me of physics and its laws, and all of that with the added advantage of studying something that had instant applications, in the form of treatment of diseases. At 18, I had a discussion with my uncle that convinced me I had made the right choice, despite my father's (an engineer) recommendation to apply to the prestigious Technical University of Athens. Instead, I entered the Medical School of the University of Athens (MSUAth), a highly competitive place, too, but lesser in my dad's eyes. Anatomy, histology, physiology, and biochemistry were my favorite subjects in MSUAth and, since I kept scoring highly in most subjects, I was quickly selected for the position of an Assistant, first at the Department of Anatomy, and then at the Department of Pharmacology, where the Chair, Prof. D Varonos, was a family friend.

In the Unit of Endocrinology of that Department, I started working as an Assistant to the Director, Prof. M Batrinos, an Endocrinologist and an absolutely wonderful person, a master teacher, real gentleman, and astute clinician. Prof. Batrinos introduced me to endocrine thinking, understanding biostatistics, and their application in clinical science. He showed me how a clinician can be a scientist, because up until then I knew I wanted to be a scientist but I could not see how bedside medicine had anything to do with my beloved bench. He also introduced me to an associate of his, Dr S Pitoulis, a biochemist who had just returned from France and was setting up a RIA-based laboratory, a first for Greece, back then. So, here I was, in the fall of 1984, a second-year medical student and at the age of 19 , setting up RIAs, labeling radiotracers with iodine, purifying first and second antibodies, and getting my first glimpse of how to produce monoclonal antibodies at the Agricultural School of Athens (ASA), Department of Veterinary Medicine, with collaborators. From ASA, I got my first opportunity to present at a meeting: I had developed the first RIA in Greece for measuring pregnant mare serum gonadotropin used for the synchronization of ovulation in Greek farm animal operations (Stratakis et al. 1987). But applying my newly acquired knowledge in human patient samples was what I found most exciting: measuring hormonal levels in the sera of patients from Prof. Batrinos' clinic (Panitsa-Faflia et al. 1990).

Soon enough, I started my graduate studies there, an impromptu MD, PhD (there were no official dual degrees at the time in Greece); in fact, I had to wait to defend my doctoral thesis until 1994, well after I finished medical school (1989). My thesis was on the measurement of

Published by Bioscientifica Ltd. 
insulin-like growth factors (IGF1 and IGF2) freed from their binding proteins (Koutsilieris \& Stratakis 1987, Stratakis et al. 1996) and the application of these assays in diurnal pituitary hormonal studies - this was the first time anybody could measure free IGFs in Greece. How fitting that I was the first recipient of the Pitoulis Young Investigator Award of the Hellenic Endocrine Society - Dr Pitoulis had taught me everything I knew in the laboratory, from gel columns to antibody purification, radioiodination, and so on. Indeed, the antibodies and most materials were homemade, something that I took particular pride in, since at the time almost everything that we used in Greece had to be imported and paid for with precious foreign currency: I certainly could not and our lab would not have been able to afford it! At the same time, I worked, first as a phlebotomist and then as a laboratory technician, for the Radioisotopes and Hormones Laboratory of a private labor and delivery hospital, Mitera. This was the era of limited ultrasound use (too new and expensive). All high-risk pregnancies were followed by daily estriol and progesterone measurements in the last trimester to determine labor. I was responsible for these assays and the delivery of results to the caring physicians. I was convinced then that endocrinology not only combined my interests in physics and chemistry with biology, but it was also an essential field of medicine. I was determined to combine my fascination with hematology-oncology (Stratakis et al. 1989a,b) with endocrinology and decided to dedicate my life to the study of endocrine tumors.

In 1987, with Prof. Batrinos' recommendation, I received a stipend to spend a summer at the Hospital Cochin, Paris, France. It was yet another life-changing experience: now, I was rounding and presenting patients to Prof. Luton and Prof. Bricaire, almost mythical names in endocrinology. The study of pituitary and adrenal gland function was now definitely my interest; Prof. Bertagna, a Luton disciple, was among my teachers and is to this day a valuable collaborator. In 1988, after I returned to Greece from France, I received a scholarship award to spend time at the National Institutes of Health (NIH) in Dr G Chrousos' laboratory, at the historic Developmental Endocrinology Branch (DEB) of the National Institute of Child Health and Human Development (NICHD). George became my mentor, later best man at my wedding, and to this date remains a close friend. I participated in the identification of the first human mutations of the glucocorticoid receptor (GR; Hurley et al. 1991) causing cortisol resistance, a disease that had been studied by George and his mentor and yet another mythical name in endocrinology, Dr Mortimer B Lipsett. I followed medical rounds at the NIH Clinical Center and was so lucky to be exposed to many more wonderful clinician scientists and outstanding teachers (Drs Lynn Loriaux, Roy Hertz, Gordon Cutler, and others); as much as I liked Paris and despite a job offer by Prof. Luton, I fell in love with NIH. I was determined to continue my work there, so a few weeks after I graduated in June 1989, I found myself back in Bethesda, MD. I continued my research on GR, finished my thesis for MSUAth (which I ended up defending in 1994), and planned my next steps: I had to finish my clinical training. It was George Chrousos who convinced me that given my interests in endocrine oncology and molecular genetics, pediatrics rather than internal medicine (which was my focus in Greece and in France) was better suited for me - the rest is history. I was accepted by the Georgetown University Department of Pediatrics, Washington, DC, where I am clinical faculty to this day. This is how and why I became a Pediatric Endocrinologist.

Medical genetics was a later love ('one's first love is always perfect until one meets one's second love'): I realized that to study the endocrine tumors I was so interested in, I had to get additional training in genetics, a field that was in the 1990s -and still is, perhaps now more than ever - at the forefront of medicine. I owe my introduction into genetics to Dr Owen Rennert, a pediatrician, a geneticist, and Chairman of Pediatrics at Georgetown University Hospital (GUH) at the time. Dr Rennert has been my mentor, 'father', and friend since; to this day, we see patients together at the NIH Clinical Center. I have to say that I was finally convinced that this was the right track for me when Dr Francis Collins, then newly appointed Director of the National Center for Human Genomics Research (which today is the National Human Genome Research Institute or NHGRI) came to GUH for one of our weekly grand rounds. His talk (as always) was so inspiring that at the end I was convinced that with proper training I would be able to find the genetic causes of the endocrine tumors I was interested in. I talked briefly to Dr Collins after rounds, and that was it: by 1996, I was board-certified in Pediatrics, Pediatric Endocrinology, and Medical Genetics and accepted the offer by Dr Athur Levine to start a small laboratory at the NIH (Unit on Genetics and Endocrinology) co-mentored by Dr Chrousos and Dr Carolyn Bondy, an absolutely wonderful clinician-scientist who had just started her now seminal work on Turner syndrome. With Chrousos' unique insights in human physiology, Bondy's help in setting up my laboratory, and Rennert's continuing advice from Georgetown, I was set, and amazingly lucky: just the right people and combination of talents to learn from!

Published by Bioscientifica Ltd. 
It is obvious from the above that during the first decade of my career, many people helped me and taught me how to 'do things' at a very young age: Prof. Batrinos entrusted me with essentially running his endocrine laboratory at age 20 (after Dr S Pitoulis' untimely death). And when I came to the United States, George Chrousos asked me, a novice in molecular biology despite my prior extensive laboratory experience, to clone in a plasmid the newly identified first mutations of the GR, an area where others in the lab had not succeeded. I surprised George when, on Christmas Eve 1989, at a dinner with his family, I showed up late from the lab with a gel image showing the mutant GR cut by the proper enzyme, and ready for transfections (I still have that gel photo).

But, there is someone I first met in 1994, who deserves a special mention: Dr J Aidan Carney - now my friend and collaborator but truly also my mentor. A physician par excellence, a true clinical investigator to whom endocrine pathology owes a host of diseases and myriad observations; and all of that, as Dr Carney always (and proudly) says, without a cent of any grant funding (!). To paraphrase the words of a song I liked as a teenager, Dr Carney doesn't 'just like medicine; he loves it' (and lives for it!). He did not need any grants to immerse himself in what he loved most - what a lesson for all of us clinician scientists! It is with Dr Carney that I have done some of the most important work of my career (Kirschner et al. 2000, Gunther et al. 2004, Horvath et al. 2006, Stratakis 2009); we continue to investigate together genetic causes of endocrine conditions to date (Stratakis \& Carney 2009, Carney et al. 2010, 2011, 2012, Carney \& Stratakis 2011, Anselmo et al. 2012).

These are all wonderful memories and to some extent vanitas vanitatum, omnia vanitas ... What are some common themes along the trajectory of my career, as it is described above, that may be useful to others?

I will reference two of my most favorite quotes, the first given to me by Dr Carney. In his Mayo Clinic office, he had a poster with the quote 'Discovery consists in seeing what everyone else has seen and thinking what no one else has thought' by Albert Szent-Gyorgyi (1937 Nobel Prize for Medicine). Dr Carney gave this poster to me when he retired from the Clinic, and today it hangs proudly in my NIH laboratory office. The other is from Albert Einstein: 'The most beautiful thing we can experience is the mysterious. It is the source of all true art and science. He to whom this emotion is a stranger, who can no longer pause to wonder and stand rapt in awe, is as good as dead: his eyes are closed' (from Einstein's Mein Weltbild (1931)).
In other words, curiosity, imagination, and drive are the jet engines that move forward any scientist; these have been my engines, too. Throughout my life I have been driven by the observations I made 'where others did not see anything', and my creativity and energy are driven by a fascination with the 'mysterious'. This is what made me swim in deep waters in Prof. Batrinos's laboratory when Dr Pitoulis passed away, and later at the NIH, in DEB, NICHD and certainly to this day. This is what keeps me 'rapt in awe' every day, not to mention my continued nonscientific writing: 'It is the source of all true art and science'.

The other important point during these formative years was the networking that is needed for anybody's career: the friends I made back then are still the most important contributors to my work today, or if not them, their friends or former trainees. For example, my French colleagues whom I met at Hospital Cochin, Paris, France, back in 1987 were instrumental: Prof. Luton introduced me then to his successor Xavier Bertagna and he, in turn, to my best friend and collaborator now Jérôme Bertherat. Jérôme introduced me to Antoine Martinez and so on ... all just wonderful people, great scientists, astute clinicians. There are several lessons here for our trainees: first, the world is small and so, second, once you have a reputation, you have a reputation. Thus, be nice to your friends, your mentors, and everybody else, for that matter. Just be nice! Third, being nice does not mean avoiding hard decisions: always be fair, even if the latter, sometimes, means not pleasing all parties. You can't afford to say yes to everyone! Eventually all good people recognize fairness - everybody recognizes justice. This is why it is important, fourth, to choose your mentors, friends, and co-workers carefully.

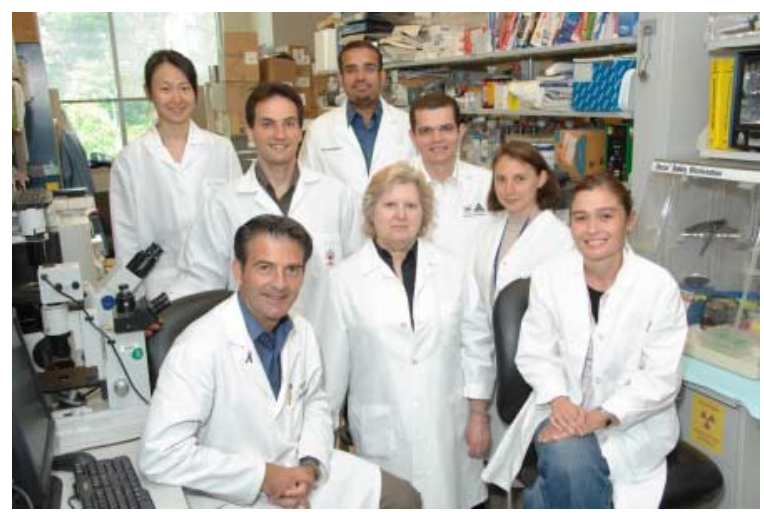

It is also clear that, like anyone in academics, I owe a lot to my trainees: I have had the fortune to have, over the years, wonderful people who have worked with me (a picture of my laboratory in 2009 is shown above).

Published by Bioscientifica Ltd 
All continue to be friends or collaborators and I enjoy tremendously seeing them with their families at meetings and other functions, thriving now as independent researchers themselves. It is my way of paying back the huge debt I owe to the many people who helped, encouraged, and taught me: to give to my graduate and medical students, fellows, and all others that I work with, all I can give: my time, advice, guidance, and opportunities. It is to my mentors as well as my trainees that I dedicated the Ernst Oppenheimer Award that I received from the Endocrine Society (shown in the picture below).

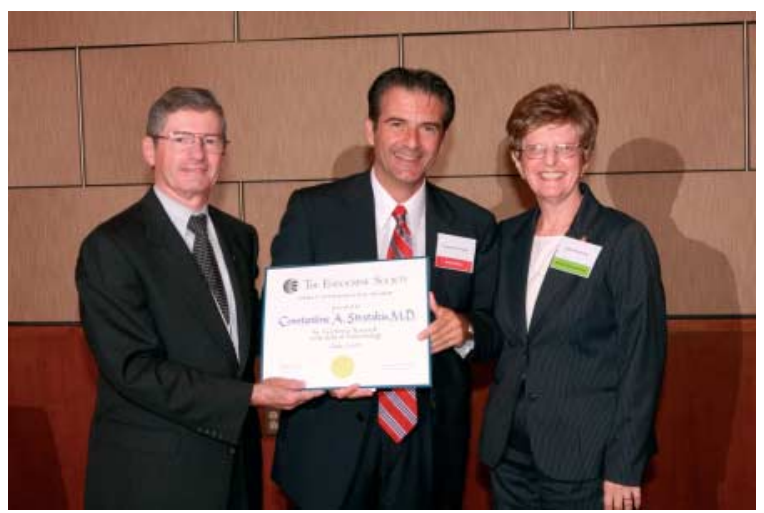

Finally, as is apparent from the introduction that I chose for this profile, it is clear that a balanced life is everything. My parents taught me, among so many other things, this need for balance, early on, and introduced me to all that I like and do today; my wife and my kids (who keep supporting my long hours at work and my traveling), my many friends, the arts, sports, the outdoors, and other hobbies (such as collecting, making, and drinking wine) nurture the mind, body, and my science.

\section{Declaration of interest}

The author declares that there is no conflict of interest that could be perceived as prejudicing the impartiality of the research reported.

\section{Funding}

This research did not receive any specific grant from any funding agency in the public, commercial or not-for-profit sector.

\begin{abstract}
Acknowledgements
I thank Endocrine-Related Cancer for asking me to complete this profile. There was no research funding that was used for this piece and the opinions and statements made above are not those of the agencies or other organizations that have funded my work. However, I do want to acknowledge the support, throughout my career, of the Intramural Research Program of the Eunice Kennedy Shriver National Institute of Child Health and Human Development (NICHD), an institution that this
\end{abstract}

year (2012) celebrates its 50th birthday and selected me recently (2011) to serve as its Scientific Director.

\section{References}

Anselmo J, Medeiros S, Carneiro V, Greene E, Levy I, Nesterova M, Lyssikatos C, Horvath A, Carney JA \& Stratakis CA 2012 A large family with Carney complex caused by the S147G PRKAR1A mutation shows a unique spectrum of disease including adrenocortical cancer. Journal of Clinical Endocrinology and Metabolism 97 351-359. (doi:10.1210/jc. 2011-2244)

Carney JA \& Stratakis CA 2011 Vilizing ovarian stromal tumor in a young woman with Carney complex. American Journal of Surgical Pathology 35 1592-1599. (doi:10.1097/PAS.0b013e31822a24a6)

Carney JA, Gaillard RC, Bertherat J \& Stratakis CA 2010 Familial micronodular adrenocortical disease, Cushing's syndrome, and mutations of the gene encoding phosphodiesterase 11A4 (PDE11A). American Journal of Surgical Pathology 34 547-555. (doi:10.1097/PAS. Ob013e3181d31f49)

Carney JA, Young WF \& Stratakis CA 2011 Primary bimorphic adrenocortical disease: cause of hypercortisolism in McCune-Albright syndrome. American Journal of Surgical Pathology 35 1311-1326. (doi:10.1097/PAS. Ob013e31821ec4ce)

Carney JA, Ho J, Kitsuda K, Young WF, Jr \& Stratakis CA 2012 Massive neonatal adrenal enlargement due to cytomegaly, persistence of the transient cortex, and hyperplasia of the permanent cortex: findings in Cushing's syndrome associated with hemihypertrophy. American Journal of Surgical Pathology 36 1452-1463. (doi:10.1097/PAS. Ob013e31825d538b)

Gunther DF, Bourdeau I, Matyakhina L, Cassarino D, Kleiner DE, Griffin K, Courkoutsakis N, Abu-Asab M, Tsokos M, Keil M et al. 2004 Cyclical Cushing's syndrome presenting in infancy: an early form of primary pigmented nodular adrenocortical disease, or a new entity? Journal of Clinical Endocrinology and Metabolism 89 3173-3182. (doi:10.1210/jc. 2003-032247)

Horvath A, Boikos S, Giatzakis C, Robinson-White A, Groussin L, Griffin KJ, Stein E, Levine E, Delimpasi G, Hsiao HP et al. 2006 A genome-wide scan identifies mutations in the gene encoding phosphodiesterase 11A4 (PDE11A) in individuals with adrenocortical hyperplasia. Nature Genetics 38 794-800. (doi:10.1038/ng1809)

Hurley DM, Accili D, Stratakis CA, Karl M, Vamvakopoulos N, Rorer E, Constantine K, Taylor SI \& Chrousos GP 1991 Point mutation causing a single amino acid substitution in the hormone binding domain of the glucocorticoid receptor in familial glucocorticoid resistance. Journal of Clinical Investigation 87 680-686. (doi:10.1172/ JCI115046)

Kirschner LS, Carney JA, Pack SD, Taymans SE, Giatzakis C, Cho YS, Cho-Chung YS \& Stratakis CA 2000 Mutations of the gene encoding the protein kinase A type I-alpha regulatory subunit in patients with the Carney complex. Nature Genetics 26 89-92. (doi:10.1038/79238)

Koutsilieris M \& Stratakis CA 1987 Regulatory mechanisms of growth hormone secretion. Materia Medica Graeca 15 431-440 (in Greek).

Panitsa-Faflia C, Stratakis C, Androutsopoulou C \& Batrinos M 1990 Effect of ovarian suppression on testosterone and dehydroepiandrosterone sulfate levels in hirsutism. Journal of Pediatric and Adolescent Gynecology 3 89-93.

Stratakis CA 1983 Physics and power analysis of the movements of vehicles. Journal of the Society of Greek Physicists - Physicos Cosmos 84 19-23 (in Greek).

Stratakis CA 2009 New genes and/or molecular pathways associated with adrenal hyperplasias and related adrenocortical tumors. Molecular and Cellular Endocrinology 300 152-157. (doi:10.1016/j.mce.2008.11.010)

Stratakis CA \& Carney JA 2009 The triad of paragangliomas, gastric stromal tumours and pulmonary chondromas (Carney triad), and the dyad of 
paragangliomas and gastric stromal sarcomas (Carney-Stratakis syndrome): molecular genetics and clinical implications. Journal of Internal Medicine 266 43-52. (doi:10.1111/j.1365-2796.2009.02110.x)

Stratakis CA, Chadio S \& Pitoulis S. Development of a radio-immuno-assay (RIA) for pregnant mare serum gonadotropins (PMSG). (oral presentation) 4th Greek Conference of Veterinary Medicine, Athens, Greece, 1987.

Stratakis CA, Demertzi E, Gerogiannis H \& Zervas J 1989a Diagnosis and treatment of Hodgkin's disease in pregnancy. Hippokrates 2 75-79 (in Greek).
Stratakis CA, Nakopoulou L, Theocharis S \& Zervas J 1989b Acute nephrotic syndrome as a manifestation of recurrent Hodgkin's disease. Hippokrates 2 391-396 (in Greek).

Stratakis CA, Mastorakos G, Magiakou MA, Papavassiliou E, Panitsa-Faflia Ch, Georgiadis E \& Batrinos M 1996 24-Hour secretion of growth hormone (GH), insulin-like growth factors -I and -II (IGF-I and -II) prolactin (PRL) and thyrotropin (TSH) in young adults of tall and normal stature. Endocrine Research 22 261-276. (doi:10.3109/ 07435809609030511)
(C) 2013 Society for Endocrinology Printed in Great Britain
Published by Bioscientifica Ltd. 